\title{
The Impact of Trainings and Experience on Teachers' Attitudes Towards the Inclusion of Children with Special Educational Needs in the Ordinary and Comprehensive Schools
}

\author{
Saranda Shatri, PhD.c. \\ Lecturer, \\ Faculty of Social Sciences, \\ $A A B$ College
}

Doi: 10.1515/ajis-2017-0021

\begin{abstract}
Teachers play a cardinal role in the implementation of quality education, and consequently the positive attitudes of teachers are crucial to the successful implementation of inclusion in education. The justification for carrying out this study lies in the fact that many children with special needs in different parts of the world but also in Kosovo are still deprived of the fundamental rights to receive education alongside their peers. Among the many obstacles and challenges, one of the main documented challenges results to be the attitudes that today's societies have to those who qualify with different abilities. Kosovo is gradually trying and taking steps to move towards a more inclusive society. In Kosovo, many governmental and non-governmental organizations have offered various programs in the vocational training of Kosovo society, among others, training of teachers with new teaching and learning methodologies. Based on this, this research focused on the impact of the trainings in the teaching at school, how the training of teachers has effected the teaching process and quality of teaching, by using as a sample the large number of trained teachers. To find out the impacts of these trainings in the teaching process, research has been conducted and the results that are presented in this paper have been extracted. The paper investigates the impact of independent variables such as: working experience as a teacher, training of teachers, and also making comparisons between regular schools and comprehensive schools in Kosovo.
\end{abstract}

Keywords: Teachers, training,, quality education, positive attitudes, inclusive schools, ordinary schools

\section{Introduction}

In Kosovo recently, governmental and non-governmental organizations have offered various programs in order to increase the level of professionalism in the Kosovo society, among others, training of teachers with new teaching and learning methodologies. This study will analyze the impact of the trainings of teachers in the teaching outcomes, by considering the large number of trained teachers. To observe the impacts of these trainings in the teaching outcomes, the research has been conducted and the results have been extracted that are presented in the following section.

During the last decades, it has not been taken more than pupils with disabilities to attend special education schools (Koster, M, Pijl, M, Jan, S, Houten, EV, Nakken, H 2007). Today, the inclusion of children with special needs in mainstream schools has become a widespread phenomenon all over the world.

Unfortunately, reality offers a different image and very few of the 150 million children in the world with disabilities have benefited from basic services such as health care and education. For 
example, United Nations estimations show that only 1 to $5 \%$ of children with disabilities attend any type of schools in developing countries. The majority are still excluded from education and society and experience daily violations of the fundamental human rights (Mittler 2004).

Teachers play a key role in the implementation of quality education and, consequently, the positive attitudes of teachers are crucial to the successful implementation of inclusion in education. The justification for carrying out this study lies in the fact that many children with special educational needs in different parts of the world and also in Kosovo are still deprived of the fundamental rights to receive education alongside with their peers. Among the many obstacles and challenges, one of the main documented challenges results to be the attitudes that today's societies have to those who are qualified with different abilities. Kosovo is gradually trying and taking steps to move towards to more inclusive society.

The paper investigates the impact of independent variables such as: working experience as a teacher, training of teachers, and also making comparisons between regularor ordinary schools and comprehensive schools.

Since the number of children is increasing and they are willingto be involved in mainstream schools in Kosovo, it is essential for teachers to be willing to work with them. Moreover, teachers should be able to train all children regardless of their background. Teachers' attitudes towards children with special needs may influence peer attitudes towards their peers with special needs. Moreover, the negative attitudes of teachers may cause parents to be skeptical that their children with special needs in ordinary classes will be able to learn if they do not trust the teacher's professionalism and if teacher is willing to adopt and teach a child with special needs in the classroom.

Trained teachers - participants in training and are supported during the first year of teaching or even years after to a certain topic, trainings are organized by the Ministry of Education and Technology and different NGOs. institutions.

Experienced teachers working with children with special educational needs in educational

\section{Research Questions}

- Research question 1: What are the perceptions of trained teachers and untrained teachers, experienced teachers, and inexperienced teachers, the two factors that influence the problems of teaching in inclusive classes?

- Research question 2: Are there differences in the perceptions of learning problems, among trained teachers for disability pupils and teachers who are not trained on this issue?

\section{Literature Review}

Training as key element ofthe professional development, even when it is available, is often short, theoretical and ineffective, and does not provide educators with opportunity to pursue professional performance. Most of the time the only form of monitoring and evaluating the teachers knowledge gained from the training are the questionnaire at the end of the trainings. In general, in Kosovo, "they report that they are in acritical shortage of high quality training programs. The 2 out of 5 schools report that they train teachers to teach comprehensively. (...) These trainings often are sponsored by NGOs, these programs rarely become widespread and organizations rarely have material resources to further extend them".

Lack of on-the-job training for the range of staff of specialists as pedagogues, psychologists and speech therapists is also a major issue since many of these professionals have been educated in what was called before the Faculty of Defectology, but recently, in many places the name has changed and to some extent the destination.

Training which has to deal with directors and organizational teachers is rare and this contributes to the lack of a comprehensive culture throughout the school. (Pantić, Closs and Ivošević, 2010) 
Teachers' attitudes are one of the most important and decisive elements for the successful follow-up of the process of inclusiveness. Teachers themselves should be aware of the importance of their attitudes in achieving the success of inclusion. They should know the importance of changing their attitudes in order to make inclusion works.

In view of attitudes, teachers should be committed, careful with their students to engage them in conversation and should not been seen as passive listeners. Teachers should be self-reflective, evaluate and re-evaluate the effectiveness of their work. (World Vision, UK (2006)

They should be willing to work closely with others, especially with their peers, parents of children, in order to find solutions to the difficult problems that arise. Living experiences and reflective thinking have been identified as good premises for the positive attitudes of teachers and candidates that aims to be a good teacher. They provide them with opportunities for the development and progressive change of teaching practices for students with special needs. (European Agency for the Development of Special Needs Education (2001).

In a research conducted by Umesh Sharma, Dennis Moore and Sanjeev Sonawane has resulted that during the first period of work as a teacher, it is important for young teachers to cope with special needs students. Such contact, if it is done systematically improves attitudes of young teachers and their behavior in the classroom. All the research has shown that the number of trainings and teachers experiences in working with children with special needs directly affect their attitudes to inclusion. Teacher training is important as they play a key role in addressing pupils' needs and seeking the necessary support resources.

Factors affecting the attitudes of teachers in the inclusive classes will be mentioned: experience in inclusive teaching; professional development of teachers; as well as administrative support. (Walker, T.J. (2012)

In the survey which is done by authors Hala Elhoweris and Negmeldin Alsheikh (2006), teachers experience is shownas an important in determining their attitudes. Teachers who have worked with children with special needs hold positive attitudes to inclusion in comparison to those who have not had such experiences. In this research, the authors also observed differences in attitudes among teachers of special schools and ordinary (Hala Elhoarweris Report and Negmeldin Alsheikh (2006).

\section{Research Methodology}

This study deals only with the teacher attitudes in Kosovo on the inclusion of children with special needs in ordinary (regular) schools depending on experience or non-experience in teaching in inclusive settings.

Befring (2004) describes the observation methodology as particularly useful for studying social facts, thoughts and attitudes in large populations.

Therefore, this is one of the fundamental reasons that this strategy is considered appropriate for this study, as the focus of this paper is to measure teachers' attitudes towards inclusion of children with special needs in ordinary (regular) schools and comprehensive schools.

The questionnaire used in this study is closer to the version of Kimani (2006), which was used to observe the views of Kenyan teachers towards inclusion. Since Kosovo has a different system from Great Britain and Kenya, adaptations have been made to this questionnaire in order to fit it as far as possible with the Kosovo context. The questionnaire was firstly translated into Kosovo by some scholars and also reviewed by experts in this field, then some modifications have been made so that the instrument improves and is better and more understandable for Kosovo teachers.

The data from the questionnaire was analyzed using a Statistical Sampling Package for Social Sciences (SPSS, Version 14).

Quantitative data analysis of the questionnaire requires that the answers to the questions to be converted to numbers. Many variables also require responses to be classified into categories. The process of converting the response to the numbers and the classification of the answers is called coding (De Vaus 2002). Therefore, the first step in SPSS data analysis was to encrypt the data to produce the Codebook.

In order to eliminate coding errors, the code location has been checked and the wrong codes 
have been corrected, this is very important because if encodings become errors, severe data problems can arise (De Vaus 2002).

As it was not possible to get people to answer the same questions in two cases, the Alfa Cronbach coefficient was used to check the reliability of the scale. Alpha should be at least 0.7 before we can say that the degree is reliable (De Vaus, 2002)

The technique used to select the sample for the quantitative part was the clustered casual sampling technique (by type of school), a technique that also makes generalization of the findings of the study.

For collecting quantitative data, we have conducted a querestionner that has three pages and consisted of 3 sections, which were distributed in 9 municipalities of the Republic of Kosovo, respectively in the municipalities of Prishtina, Gjakova, Klina, Ferizaj, Mitrovica, Skenderaj, Drenas, Gjilan and Rahovec / Orahovac; the selection criteria was to slect one comprehensive school and one ordinary school; 358 questionnaires were distributed in total. The objective of the research was to distribute the them in the schools in the city center, away from the center and rural schools of these districts.

The questionnaire was distributed to the teachers from comprehensive elementary school, grades 1-5, and ordinary schools that had approximately the same number of teachers with inclusive schools and the questionnaire period covered the second half of the academic year 20152016, from which 297 questionnaires were collected, which means 83\% of the distributed questionnaires were collected. Questionnaires were filled up by the teachers and were done in the best way in their natural environment and without any influence from outside, and the supplements were also carried out completely independently.

\section{Results}

The overall results that are derived from the processing of quantitative data of this study and data processing is done based on the research questions.

For the analysis of the data, relevant tests were used to answer the research questions of this paper. The frequency analysis and the percentages of the working data are applied to analyze the descriptive data. To analyze the differences, which can be observed according to the demographic data of the participants in this paper, crosstabulation analysis was used.

\section{Findings}

Table 1: Descriptive statistics on the number of participants by type of school; Ordinary (Regular) Schools and Inclusive (comprehensive) Schools.

\begin{tabular}{|l|c|c|}
\hline Valid & Frequency & Percent \\
\hline 1 Ordinary schools & 147 & 49.50 \\
\hline 2 Inclusive schools & 150 & 50.50 \\
\hline 3 Total & 297 & 100,0 \\
\hline
\end{tabular}

According to Table 1, there were one hundred and forty-seven teachers (49.5\%) from regular schools and one hundred and fifty teachers (50,50\%) were from a comprehensive school or had experience in inclusive education that participated in this study.

Table 2: Descriptive statistics on the gender of teachers

\begin{tabular}{|l|c|c|}
\hline Gender of teachers & Frequency & Percent \\
\hline 1 Femal & 264 & 88.90 \\
\hline 2 Male & 33 & 11.10 \\
\hline 3 Total & 297 & 100 \\
\hline Missing System (lost value) & 4 & 1,3 \\
\hline Total & 301 & 100 \\
\hline
\end{tabular}


As shown in Table 2, female teachers were in the majority compared to male teachers: there were two hundred and sixty-four female teachers $(88,90 \%)$ and thirty three male teachers $(11,10 \%)$ who participated in this study. Four teachers $(1,3 \%)$ did not show their gender (Table 2$)$

Table 3: Descriptive Statistics on Teacher's Education Experience in Inclusive Schools

\begin{tabular}{|c|l|c|c|c|c|}
\hline \multicolumn{6}{|c|}{ Inclusive Schools } \\
\hline \multirow{4}{*}{ Valid } & Frequency & Percent & Valid Percent & Cumulative Percent \\
\hline \multirow{4}{*}{} & $0-5$ years old & 23 & 15.3 & 15.3 & 15.3 \\
\cline { 2 - 6 } & $6-10$ years old & 38 & 25.3 & 25.3 & 40.7 \\
\cline { 2 - 6 } & $11-20$ years old & 54 & 36.0 & 36.0 & 76.7 \\
\cline { 2 - 6 } & Above 20 years old & 35 & 23.3 & 23.3 & 100.0 \\
\cline { 2 - 6 } & Total & 150 & 100.0 & 100.0 & \\
\hline
\end{tabular}

Table 4: Descriptive Statistics on Teacher's Education Experience in Regular Schools

\begin{tabular}{|c|c|c|c|c|c|}
\hline \multicolumn{6}{|c|}{ Regular Schools } \\
\hline & & Frequency & Percent & Valid Percent & Cumulative Percent \\
\hline \multirow{5}{*}{ Valid } & $0-5$ years old & 11 & 7.5 & 7.5 & 7.5 \\
\hline & $6-10$ years old & 25 & 17.0 & 17.0 & 24.5 \\
\hline & $11-20$ years old & 64 & 43.5 & 43.5 & 68.0 \\
\hline & Above 20 years old & 47 & 32.0 & 32.0 & 100.0 \\
\hline & Total & 147 & 100.0 & 100.0 & \\
\hline
\end{tabular}

In inclusive schools, the largest number of teachers have an education experience of 11-20 years, 54 teachers $(36.0 \%)$ and the lowest number of teachers in these schools are 23 or $15.3 \%$ who have experience up to 5 years.

In regular schools we have the most number of teachers with 11-20 years of experience, 64 teachers $(43.5 \%)$ and the lowest number of teachers we have for up to 5 years, 11 teachers or (7.5\%.)

Based on this data, we notice that in regular schools, the number of teachers over 20 years, 47 teachers or (32\%), is higher than in inclusive schools which is 35 teachers or $(23.3 \%)$.

This shows that in regular schools we have teachers with longer experience in education than in inclusive schools.

Table 5: Descriptive statistics on teachers training for working with children with special educational needs, in Inclusive (comprehensiv schools

\begin{tabular}{|c|c|c|c|c|c|}
\hline \multicolumn{9}{|c|}{ Inclusive Schools } \\
\hline \multirow{3}{*}{ Valid } & Frequency & Percent & Valid Percent & Cumulative Percent \\
\cline { 2 - 6 } & No & 79 & 52.7 & 52.7 & 52.7 \\
\cline { 2 - 6 } & Total & 150 & 47.3 & 47.3 & 100.0 \\
\hline
\end{tabular}

Table 6: Descriptive statistics on teachers training for working with children with special educational needs, in regular (ordinary) schools.

\begin{tabular}{|c|c|c|c|c|c|}
\hline \multicolumn{9}{|c|}{ Regular Schools } \\
\hline \multirow{2}{*}{ Valid } & Yes & 86 & 58.5 & 58.5 & Cumulative Percent \\
\cline { 2 - 6 } & No & 61 & 41.5 & 41.5 & 58.5 \\
\cline { 2 - 6 } & Total & 147 & 100.0 & 100.0 & 100.0 \\
\hline
\end{tabular}

In inclusive (comprehensive) schools, there are no significant differences between trained teachers, 79 teachers $(52.7 \%)$, and 71 uneducated teachers $(47.3 \%)$. 
In regular schools we have 86 teachers or $58.5 \%$ trained and 61 teachers or $41.5 \%$ untrained. As we can see, the number of trained teachers is greater in regular schools.

\section{Discussion}

Moreover, this study has shown that experience in working with children with NVA has big impact and it shows the difference between teachers' attitudes towards inclusion. More specifically, it was found that experienced teachers in working with children with NVA posess more positive attitudes to their inclusion than their unexperienced colleagues. This finding is also supported by studies conducted in other countries (eg, Avramidis et al., 2000; Gilmore, Campbell, and Cuskelly, 2003; Stoiber et al., 1998; Wisart, 2001).

Initially, the general attitude of teachers in regular schools was measured, regardless of their experience in inclusive education. Thereafter, the study compared these attitudes of "experienced" and "inexperienced" teachers to inclusive education to determine whether there has been a change in attitudes about the experiences of those non-experienced teachers in inclusive education, as a sample we used to have 20 pupils (students) in the classroom.

According to the results obtained from the study, it turns out that older teachers were much more negative in terms of inclusion. This tendency or finding can be partly explained by the fact that older teachers did not gain knowledge and skills in their education during this schooling or did not develop specific subjects for inclusion schools because they were part of the education system where students with special needs attended classes at special schools, and also lived in a time when children with disabilities were isolated from society. The jugment that children with special needs have functioned and served better in special schools is still present in the discussions of teachers in Kosovo. Inclusive education seems unworkable to many of them.

Experienced teachers had more positive attitudes than inexperienced teachers. According to findings, trainings for the teachers development in special needs education and inclusive education practices are important factors in developing more positive attitudes towards inclusion.

In Kosovo after the war, many trainings were held for teachers, organized by the Ministry of Education, Science and Technology as well as local and international NGOs.

Trainings that were held for teachers had a more informative character in which teachers were familiar with the characteristics of children with special needs, which was not enough for teachers. Our teachers need additional training where the main focus should be on access to children with special needs.

\section{Conclusion}

In this study we have used a sample of 297 teachers from primary or elementary and secondary school, the academic year when the study is conducted was the year 2015-2016, and is good to mentioned that $88.9 \%$ of the participants were female teachers and only $11.1 \%$ of them were male teachers. This percentage is justified by the fact that in the education system of Kosovo this is very noticeable, because most of the teachers covering these programs are female teachers.

From this data we can say that teachers in elementary schools are teachers who have a considerable experience, with long experience in teaching showing some degree of security in addressing the problems, this was also said by the "specialist" from a perspective in teaching, where any given opinion can be considered highly specialized.

The motivation of this study are the results of the survey, which shows that teachers were very interested and persistent regarding the training on the recognition of "Children with special educational needs" and "Teaching" them, by gaining extra knowledge and skills for their adaptation and needs that have these pupils with special needs. Around $41.5 \%$ of teachers stated they were untrained and showed that they wanted to work with these pupils but in a very sincere way they expressed that they did not know how to work with them.

As the conclusion on the main findings of the study, we summarized in the first question of study: - "What are the perceptions of male teachers and female teachers, trained teachers and unskilled teachers, experienced teachers and less experienced teachers in teachingat inclusive 
classes "? It has been concluded that teachers' perceptions about efficacy in teaching strategy, classroom efficiency and pupils (or students) motivation efficiency have emerged that are at high level. Regarding the attitudes of teachers with disabilities students in inclusive classes, it has emerged that teachers have indifferent attitudes regarding the inclusion of these pupils (or students).

\section{Recommendations}

For teacher from inclusive classes to have teaching efficiencies and positive attitudes towards inclusion and integration of children with disability (special needs) in the learning process, the following recommendations are given based on the findings of the study by using quantitative analysis. These recommendations could serve teachers that teach at inclusive classes, inspectors dealing with training problems as well as new teachers to have a good attitude and performance in the inclusive (comprehensive) teaching.

Recommendation 1. Based on the results is proven statistically asignificant differences between trained and untrained teachers, regarding the efficiency in teaching strategy and being efficient in managing the classroom, and it is recommended to provide explicit training to these factors.

Recommendation 2. Trainings on the designing and implementing PEI for teachers that are involved in inclusive classes; on the recognition of the types of disability, pupils as well as the differentiated and contemporary teaching, make the teaching of these well-studied students in terms of short-term and long-term objectives.

\section{References}

Avramidis, E. Bayliss, P, Burden, R 2000, 'A Survey into Mainstream Teachers' Attitudes Towards the Inclusion of Children with Special Educational Needs in the Ordinary School in one Local Education Authority', Educational Psychology. An International Journal of Experimental Educational Psychology, Viewed 5 September 2016.

David De Vaus, 2002, " Surveys in Social Research, Edition :5th, Publisher: Allen \&Unwin, St. Leonardds, NSW

Haxhiymeri, V., (2003). Mbi Veprimtarinë dhe Arritjet e Projekti "Asimit Special i Integruar": Arritje, Sugjerime, Sfida për të Ardhmen në Kuadër të Arsimit Gjithëpërfshirës, fq. 85

Kalyva, E., Gojkovic, D.\& Tsakiris, V. (2007). Serbian Teachers' Attitudes Towards Inclusion. International Journal of Special Education. Vol. 22, No.3, pp 30-35.

Koster, M, Pijl, M, Jan,S, Houten, EV, Nakken, H 2007, 'The social position and development of pupils with SEN in mainstream Dutch primary schools'. European Journal of Special Needs Education, 01 February

Lindsey, G 2007, 'Educational psychology and the effectiveness of inclusive education/mainstreaming', British Journal of Educational Psychology, Vol.77, pp.1-24. The British Psychological Society. Viewed 7 Oktomber 2007, www.bpsjournals.co.uk

Marshal, J, Ralph, S, Palmer, S 2002, 'I wasn't trained to work with them': mainstream teachers' attitudes to children with speech and language difficulties', International Journal of Inclusive Education, vol.6, No.3, pp. 199-215.

Ministria e Arsimit, Shkencës dhe e Teknologjisë, Treguesit dhe të dhënat statistikore në arsim, 2004/05, 05/06, 06/07, Prishtinë, 2008

Mittler, P 2004, 'Including children with disabilities'. Prospects, vol. XXXIV, no.4, December 2004.

Nora E. Groce, Raport Përmbledhës. Dhuna kundër fëmijëve me aftësi të kufizuara (Violence against Children with Disabilities), Studim mbi Dhunën kundër fëmijëve (Study on Violence against Children), nga Sekretari i Përgjithshëm i KB, Grupi Tematik mbi Dhunën ndaj fëmijëve me aftësi të kufizuara (Thematic Group on Violence against Children ëith Disabilities), UNICEF, 2005, fq. 15 dhe 5

Opdal, L. R., Wormns, S., \& Habayeb, A. (2001). Teachers' opinions about inclusion: A pilot study in a Palestinian context. International Journal of Disability, Development and Education, 48 (2), 143-162.

Pantiç, Natasha, Alison Closs dhe Vanja Ivošević, Mësuesit për të ardhmen: Zhvillimi i mësuesve për arsimin gjithëpërfshirës në Ballkanin Perëndimor (Teachers for the Future: Teacher Development for Inclusive Education in the Western Balkans), FET, gusht 2010. E disponueshme tek katalogu me mundësi kërkimi, tek: http://www.etf.europa.eu/web.nsf/pages/Publications_catalogue 